\title{
EFFECT OF SODIUM SALT OF GLUCOSE CYCLO- ACETOACETATE ON THE BIOSYNTHESIS OF ASCORBIC ACID IN RIBOFLAVIN DEFICIENT RATS
}

\author{
M. C. NATH AND J.S. DHEER \\ University Department of Biochemistry, Nagpur, India
}

(Received December 9, 1966)

The interrelationship between the vitamins of $\mathrm{B}$ group and vitamin $\mathrm{C}$ has been studied by a number of workers $(1-6)$. They have demonstrated by in vivo experiments that under deficiency of thiamine, riboflavin, pantothenic acid or folic acid both the urinary excretion as well as tissue reserve of ascorbic acid in rats are greatly diminished. Chatterjee et al. (7) have shown diminished synthesis of ascorbic acid by the microsomes of riboflavin-deficient rats. Their study confirms the past works on the interrelationship of B-vitamins and ascorbic acid. From their investigations it was observed that riboflavin performs one of the major roles in the biosynthesis of ascorbic acid. It has been shown by Nath and Shastri (8) that in mung beans there is an increased synthesis of riboflavin in the presence of glucose cycloacetoacetate (GCA). Investigations were, therefore, carried out to see whether GCA, which has been shown to help in the synthesis of riboflavin, could spare riboflavin for the synthesis of vitamin $\mathrm{C}$ in riboflavin-deficient rats.

\section{EXPERIMENTAL}

Male albino rats weighing about $100-150 \mathrm{~g}$ were taken and divided into three groups (6 in each group). All the three groups were placed on a riboflavin-deficient diet. The diet used was mainly that of Friedman, Shue and Hove (9) except that groundnut oil was used instead of cottonseed oil and Hawk-Oser salt mixture was used instead of Jones-Foster salt mixture. Composition of the diet is given in Table 1. Group I received only riboflavin-deficient diet. In addition, Group II received daily $100 \mathrm{mg}$ of sodium salt of GCA (10) injections intraperitoneally. Group III received daily injections of $25 \mu \mathrm{g}$ of riboflavin intraperitoneally. Urine estimations for vitamin C (11) were done in the beginning and after that periodically. Weights of the individual rats of the different groups were also taken periodically. When signs of acute riboflavin deficiency appeared in the rats of group I, after 8 weeks, all the animals were killed by decapitation, blood collected in oxalated tubes, liver removed, chilled and weighed. Before killing the rats 24 hour urine samples were collected for estimations of ascorbic acid by Roe and Kuether's method (11) and riboflavin by Najjar's method (12). Blood and liver ascorbic acid estimations were done by Roe and Kuethers' method (11). Serum 
TABLE 1

Composition of Riboflavin Deficient Diet

\begin{tabular}{|c|c|c|c|c|}
\hline \multicolumn{2}{|r|}{ Constituent } & & \multicolumn{2}{|c|}{$\mathrm{g} / 100 \mathrm{~g}$ diet } \\
\hline \multirow{6}{*}{\multicolumn{2}{|c|}{$\begin{array}{l}\text { Sucrose } \\
\text { Casein (vitamin free) } \\
\text { Salt Mixture (Hawk-Oser) } \\
\text { Groundnut oil } \\
\text { Codliver oil U.S.P. } \\
\text { Vitamin supplement } a\end{array}$}} & & & 65 \\
\hline & & & & 20 \\
\hline & & & & 4 \\
\hline & & & & 8 \\
\hline & & & & 2 \\
\hline & & & & 1 \\
\hline \multicolumn{5}{|c|}{$\begin{array}{l}\text { Vitamins per } 100 \mathrm{~g} \text { diet (in } \mathrm{mg} \text { ): thiamine hydrochloride, } 5 \text {; pyridoxine hydro- } \\
\text { chloride, } 6 \text {; calcium pantothenate, } 25 \text {; nicotinamide, } 20 ; \mathrm{D} \text {-biotin, } 0.1 \text {; folic acid, } \\
2 \text {; vitamin } \mathrm{B}_{12}, 0.2 \text {; inositol, } 200 \text {; choline chloride, } 2000 \text {. }\end{array}$} \\
\hline \multicolumn{5}{|c|}{$\begin{array}{c}\text { TABLE } 2 \\
\text { Ascorbic Acid in Urine, Blood and Liver }\end{array}$} \\
\hline \multirow{2}{*}{\multicolumn{2}{|c|}{ Group }} & & & \\
\hline & & Urine & Liver & Blood serum \\
\hline $\mathrm{I}$ & Riboflavin-deficient & $\begin{array}{c}m g / r a t / d a y \\
0.33 \pm 0.08\end{array}$ & $\begin{array}{l}m g / 100 \mathrm{~g} \text { wet } w t \\
16.5 \pm 1.8\end{array}$ & $\begin{array}{l}m g / 100 m l \\
0.73 \pm 0.18\end{array}$ \\
\hline II & $\begin{array}{l}\text { Riboflavin-deficient } \\
\text { injected with riboflavin } a\end{array}$ & $0.52 \pm 0.21$ & $21.0 \pm 1.3$ & $0.98 \pm 0.21$ \\
\hline III & $\begin{array}{l}\text { Riboflavin-deficient } \\
\text { injected with } \mathrm{Na} \mathrm{GCA}{ }^{b}\end{array}$ & $0.69 \pm 0.15$ & $26.0 \pm 2.4$ & $1.18 \pm 0.23$ \\
\hline
\end{tabular}

$a$ Dose : $25 \mu \mathrm{g} / \mathrm{rat} /$ day $\quad{ }^{b}$ Dose : $100 \mathrm{mg} / \mathrm{rat} /$ day

TABLE 3

Riboflavin in Liver, Blood and Urine

\begin{tabular}{cccc}
\hline \hline Group $a$ & Urine & Liver & Blood serum \\
\hline & $\mu g / 6$ rats $/$ day & $m g / 100 g$ wet weight & $\mu g / 100 m l$ \\
I & $2.8 \pm 0.84$ & $1.23 \pm 0.21$ & $0.8 \pm 0.15$ \\
II & $18.6 \pm 1.32$ & $3.2 \pm 0.24$ & $2.52 \pm 0.44$ \\
III & $3.3 \pm 1.82$ & $2.18 \pm 0.18$ & $1.92 \pm 0.32$ \\
\hline
\end{tabular}

$a$ Group description is the same as in Table 2 .

riboflavin was estimated by the method of Burch, Bessay and Lorry (13) and liver riboflavin by the colorimetric method of Snell and Snell (14). The results are presented in Tables 2 and 3.

\section{RESULTS AND DISCUSSION}

From Table 2 it is seen that in the riboflavin-deficient rats there is less urinary excretion of ascorbic acid, which is in confirmation of the previous work. In the riboflavin-deficient rats injected with sodium salt of GCA and in the deficient rats receiving riboflavin injections, there is more urinary excretion of ascorbic acid. Ascorbic acid in liver and serum showed diminished quantity in riboflavin-deficient rats than in the groups injected with sodium salt of GCA and riboflavin. Decreased level of ascorbic acid in riboflavin-deficient rats confirms the observation of the previous workers that under the deficiency of riboflavin there is an impairment of ascorbic acid synthesis in rats $(1-6)$. Nath and Shastri reported an 
increased synthesis of riboflavin in germinating mung beans with GCA (8). In the present studies, results show no increase in the riboflavin levels in riboflavin deficient rats injected with sodium salt of GCA (Table 3). However, vitamin C has been maintained at the normal levels in this group. Earlier workers from this laboraroty showed that GCA helped in the synthesis of vitamin $\mathrm{C}$ in mung beans and rats $(15,16)$. Since riboflavin is not only a stimulating factor for this enzyme responsible for the synthesis of vitamin $C$, it is possible that sodium salt of GCA may be stimulating the enzymes to synthesize vitamin $\mathrm{C}$ and thus replacing riboflavin or it may be suggested that synthesis of vitamin C from GCA may not be requiring the presence of riboflavin. It seems from the results that riboflavin is spared or replaced by GCA for the synthesis of vitamin C.

\section{SUMMARY}

In the present paper the role of glucose cycloacetoacetate (GCA) in vitamin C synthesis of riboflavin-deficient rats was studied. It is evident from the results that GCA helps in maintaining vitamin C levels in blood and tissues of riboflavindeficient rats.

\section{ACKNOWLEDGEMENT}

The authors wish to record their grateful thanks to the Council of Scientific and Industrial Research, India for financial assistance.

\section{REFERENCES}

1. Roy, S. C., Roy, S. K., and Guha, B.C., Nature, 158, 238 (1946).

2. Chatterjee, G. C., Roy, S.C., and Guha, B. C., Ann. Biochem. Exp. Med., 15, 191 (1955).

3. Roy, S. N., Gyorgy, P., and Harris, L. J., Biochem. J., 29, 735 (1935).

4. Sure, B., Theis, R. M., and Harrelson, R. T., J. Biol. Chem., 129, 245 (1939).

5. Schwartz, M. A., and Williams, J. N. (Jr.), J. Biol. Chem., 197, 481 (1952).

6. Thangamani, A., and Sarma, P.S., Curr. Sci., 26, 72 (1957).

7. Chatterjee, I. B., Ghosh, N. C., Ghosh, J. J., and Guha, B. C., Science, 126, 608 (1957).

8. Nath, M. C., and Shastri, N. V., Indian J. Exp. Biol., 4, 184 (1966).

9. Friedman, L., Shue, G. M., and Hove, E. L., J. Nutrition, 85, 309 (1965).

10. Nath, M. C., Sahu, V.K., and Behki, R. M., Metabolism, 1, 18 (1956).

11. Roe, J. H., and Kuether, C. A., J. Biol. Chem., 147, 399 (1943).

12. Najjar, V. A.. J. Biol. Chem., 141, 355 (1941).

13. Burch, H. B., Bessay, O. A., and Lowry, O. H., J. Biol. Chem., 175, 457 (1948).

14. Snell, F. D., and Snell, C. T., Colorimetric Methods of Analysis, 4, 303 (1954).

15. Nath, M. C., Belavady, B., Sahu, V. K., and Chitale, R. P., Proc. Soc. Exp. Biol. Med., 83, 39 (1953).

16. Nath, M. C., and Belkhode, M. L., Nature, 183, 1258 (1959). 